\title{
POTENSI ANTIMIKROBA CENGKEH : REVIEW LITERATUR
}

\author{
Marko Jeremia Kalalo ${ }^{1 *}$, Berta Gratia ${ }^{1)}$, Crunny Bidhya Bidulang' ${ }^{1)}$, Fadillah \\ Djafar $^{1)}$, Hosea Jaya Edy ${ }^{1)}$ \\ 1) Program Studi Farmasi, Fakultas Matematika dan Ilmu Pengetahuan Alam, Universitas \\ Sam Ratulangi \\ *Corresponding author email: markojeremiakalalo@gmail.com
}

\begin{abstract}
Popularity of bioactive compounds from plants as a treatment for microbial infections have increased. The content of chemical compounds in cloves can produce various biological activities. The chemical compounds contained in cloves are phenol, flavonoid, hydroxybenzoate, and hydrokinetic acid, with the main chemical compound being eugenol. This review was prepared using secondary data from the scientific literature databases of Google Scholar, PubMed, and CORE. This review aims to collect, compile, study, and highlight the potential of cloves as an antimicrobial agent from existing literature and databases. The effectiveness of cloves in treating microorganisms has a broad spectrum, including bacteria, fungi, protozoa, and viruses. The antimicrobial activity of ethanol, methanol, acetone extract, and clove essential oil provided antimicrobial activity against Gram-positive and Gram-negative bacteria. Cloves show bacteriostatic and bacteriocidic activity with mechanism of action in disrupting or damaging cell wall.
\end{abstract}

Keywords : antimicrobial, clove.

\begin{abstract}
ABSTRAK
Popularitas senyawa bioaktif tanaman sebagai penanganan infeksi mikroba kian meningkat. Kandungan senyawa kimia cengkeh dapat menghasilkan berbagai aktivitas biologi. Senyawa kimia yang terkandung dalam cengkeh adalah fenol, flavonoid, hidroksi benzoat, dan asam hidrokinetik, dengan kandungan senyawa kimia utama eugenol. Review ini dibuat menggunakan data sekunder dari database literatur ilmiah Google Scholar, PubMed, dan CORE. Review ini bertujuan untuk mengumpulkan, menyusun, mengkaji, dan menyorot potensi cengkeh sebagai agen antimikroba dari literatur dan database yang ada. Efektivitas cengkeh dalam menghabat mikroorganisme memiliki spektrum yang luas mencakup bakteri, jamur, protozoa, dan virus. Aktivitas antimikroba ekstrak etanol, metanol, aseton, minyak atsiri cengkeh memberikan aktivitas antimikroba pada bakteri Gram positif dan Gram negatif. Cengkeh menunjukkan aktivitas bakteriostatik dan bakteriosidik dengan mekanisme merusak dinding sel.
\end{abstract}

Kata kunci : antimikroba, cengkeh 


\section{PENDAHULUAN}

Popularitas senyawa bioaktif minyak esensial dari tanaman sebagai penanganan infeksi mikroba yang telah mengalami resistensi kian meningkat (Cui et al., 2019). Minyak esensial banyak dikembangkan sebagai alternatif alami dari senyawa-senyawa sintetik yang tersedia. (Simas et al., 2017). Tanaman dianggap sebagai salah satu sumber dari senyawa-senyawa bioaktif yang dapat memberikan efek antimikroba (Mesquita dan Tavares, 2018).

Minyak esensial mengandung metabolit sekunder seperti terpenoid dan sesquiterpen yang berperan dalam aktivitas biologisnya (Cunha et al., 2005). Kuantitas dan komposisi dari minyak esensial bervariasi pada setiap tumbuhan bergantung pada genetik dan fisiologi tumbuhan serta kondisi saat ditanam, panen, setelah panen, dan kondisi lingkungan (Costa et al., 2008).

Ekstraksi cengkeh memiliki kandungan minyak esensial yang menonjol diantara tanaman obat lainnya. Cengkeh ( $S$. aromaticum) digunakan dalam perang dunia II sebagai tanaman obat untuk tentara yang terluka dalam perang (Cunha and Roque, 2013). Cengkeh (S. aromaticum) digunakan di mayarakat sebagai antibakteri, antioksidan, rempah, dan penyedap makanan (Rivas et al., 2015).

Kandungan senyawa kimia cengkeh dapat menghasilkan berbagai aktivitas biologi. Senyawa kimia yang terkandung dalam cengkeh adalah fenol, flavonoid, hidroksi benzoat, dan asam hidrokinetik, dengan kandungan senyawa kimia utama eugenol (CortésRojas et al., 2014).

Review ini bertujuan untuk mengumpulkan, menyusun, mengkaji, dan menyorot, potensi cengkeh sebagai agen antimikroba dari literatur dan database yang ada.

\section{METODE PENELITIAN}

Review ini dibuat menggunakan data sekunder dari database literatur ilmiah Google Scholar, PubMed, dan CORE. Artikel muncul di hasil pencarian dengan menggunakan kombinasi kata kunci: "cengkeh OR clove", "Antimicrobial OR Antimikroba", "Antibacterial OR Antibakteri", "Antiviral OR Antivirus", "Antifunggal OR Antijamur", "Antiprotozoa".

Proses pencarian dan seleksi diselesaikan pada Oktober-Desember 2020 secara independen oleh 4 author, lalu dikonsultasikan kepada 1 author lainnya. Artikel yang diambil adalah yang memiliki data antimikroba cengkeh. Artikel review dan metanalasis dieksklusikan.

Seleksi dilakukan dengan menghapus artikel yang terduplikasi dan mengevaluasi artikel dengan membaca judul, absrak, dan seluruh artikel. Sintesis data dilakukan terhadap artikel tersebut.

\section{HASIL DAN PEMBAHASAN Aktifitas Antimikroorganisme}

Cengkeh memiliki aktivitas antimikroba yang luas karena dapat menghambat bakteri, jamur, protoza, dan virus. Mikroorganisme yang dihambat atau dibunuh oleh cengkeh terdapat pada lampiran 1. Cengkeh memiliki spektrum anti bakteri yang luas. Nilai MIC terhadap bakteri Gram positif dan Gram negatif menunjukkan daya hambat yang baik. Cengkeh menunjukkan daya bunuh terhadap beberapa bakteri (Pathirana et al, 2019). Inhibisi terhadap bakteri Gram positif lebih besar daripada inhibisi pada bakteri Gram positif (Saikumari et al, 2016), akan tetapi cengkeh menunjukkan nilai MIC terhadap beberapa bakteri Gram negatif yang sangat rendah atau sangat kuat (Moon et 
al, 2011; Pandey dan Singh, 2011; Pathirana et al, 2019).

Kombinasi dengan agen antibakteri lain berpotensi menghasilkan aktivitas antibakteri yang sinergis (Zainol, 2017; Kumar et al, 2014). Cengkeh dapat menjadi agen soportif terapi antibiotik. Kombinasi dengan antibiotik menunjukkan adanya penurunan nilai MIC maupun $\mathrm{MBC}$ terhadap bakteri. Kombinasi cengkeh dan antibiotik oral seperti gentamicin dan ampicilin dapat memberikan efek sinergis dalam menginhibisi biofilm bakteri (Moon et al, 2011).

Minyak atsiri cengkeh dapat terdisolusi dan terakumulasi serta merusak membran bakteri. Kerusakan pada membran memiliki korelasi langsung dengan kematian sel bakteri. Mekanisme baktesidal eugenol adalah mendisrupsi membran sitoplasma (Nuñez dan D'Aquino, 2012). Aktivitas antibakteri minyak atsiri menunjukkan efek yang signifikan terhadap rate of surviving $S$. aureus. Waktu dan konsentrasi terapi minyak atsiri memiliki pengaruh terhadap efek biologisnya. Perusakan terhadap dinding sel ditunjukkan melalui peningkatan alkalin fosfatase dan prolonggasi waktu inkubasi terjadi seiring dengan penambahan konsentrasi minyak atsiri. Alkalin fosfatase terdapat diantara dinding sel dan membran sel. Perusakan dinding sel menyebabkan celah dan melepaskan alkalin fosfatase. Perusakan dinding sel juga ditandai dengan berkurangnya elektrolit sel seperti $\mathrm{K}^{+}, \mathrm{Ca}_{2}{ }^{+}, \mathrm{Na}^{+}$. Uji SDS-PAGE menunjukan adanya pengurangan 5 noda protein yang menunjukkan minyak atsiri memiliki efek antibakteri dengan merusak maupun menginhibisi sintesis protein tetapi tidak memiliki aktivitas ikatan dengan DNA (Xu et al, 2016).

Senyawa bioaktif cengkeh beropotensi memberikan aktivitas antiviral dengan menjadi inhibitor terhadapt enzim virus
(Saleem et al, 2019). Cengkeh dapat mencegah pembentukan cyst pada protozoa. Kemampuan ini sangat penting karena pembentukan cysts selama terapi dapat menyebabkan kegagalan terapi (Anacarso et al, 2017). Eugenol pada cengkeh menginhibisi aktivitas enzim ATPase, histidine decarboxylase, amylase, dan protease yang dapat berujung pada kematian sel dan menghambat pertumbuhan mycelium (Hamini-Kadar et al, 2014). Eugenol merupakan komponen utama yang bertanggung jawab dalam aktivitas antifungi karena dapat menyebabkan lisis dari spora dan micelles pada jamur. Pengamatan mikroskopis menunjukkan terjadinya pembengkakan dan kerusakan pada spora yang diberikan eugenol (Yazdanpanah dan Mohamadi, 2014).

Berdasarkan uji aktivitas antibakteri dari ekstrak bunga cengkeh terhadap bakteri Streptococcus mutans dengan metode difusi agar menunjukkan bahwa, ekstrak bunga cengkeh berpotensi sebagai antibakteri karena adanya aktivitas penghambatan dari ekstrak bunga cengkeh terhadap bakteri S.mutans dengan terbentuknya zona hambat disekitar sumuran/cakram. Diameter zona hambat ekstrak yang diperoleh lebih besar dibandingkan kontrol positifnya yaitu ampicillin. Adanya zat-zat aktif pada bunga cengkeh menyebabkan terbentuknya zona hambat. Senyawa bersifat antibakteri seperti alkaloid, flavonoid, terfenoid, dan fenolik ini terdapat dalam bunga cengkeh (Suhendar dan Fathurrahman, 2019).

Zahro dan Agustini (2013) mengemukakan bahwa, terdapat beberapa klasifikasi aktivitas antibakteri berdasarkan zona hambatnya, yaitu : Aktivitas aktibakteri lemah jika diameter zona hambatnya $<5 \mathrm{~mm}$, sedang jika diameter zona hambatnya 5$10 \mathrm{~mm}$, kuat jika diameter zona 
hambatnya $10-20 \mathrm{~mm}$ dan sangat kuat jika diameter zona hambatnya $>20 \mathrm{~mm}$. Berdasarkan klasifikasi ini maka aktivitas antibakteri ekstrak bunga cengkeh dengan diameter zona hambat $>20 \mathrm{~mm}$ tergolong sangat kuat terhadap $S$. mutans yang menunjukkan bahwa senyawa antibakteri yang terkandung di dalam ekstrak metanol Bunga cengkeh memiliki aktivitas penghambatan yang besar terhadap $S$. mutans. Untuk hasil uji Konsentrasi Hambat Minimun (KHM) ekstrak metanol bunga cengkeh terhadap bakteri $S$. mutans menunjukkan bahwa semakin tinggi konsentrasi ekstrak bunga cengkeh menyebabkan semakin tinggi pula penghambatan terhadap bakteri (Suhendar dan Fathurrahman, 2019).

Kandungan Senyawa Kimia
Cengkeh

Kandungan senyawa dalam cengkeh terdapat pada lampiran 2. Salah satu senyawa yang biasa digunakan dalam industri farmasi karena memiliki banyak aktivitas senyawa farmakologi sebagai antiseptik, antiinflamasi, antiviral, antimikroba, antifungal, antispamosdik, stimulan, anastestik lokal adalah eugenol (Alisa et al, 2015). Eguenol mampu menghambat bakteri gram positif dan juga negatif hingga pada bakteri yang resisten terhadap antibiotik. Karena sifatnya yang hidrophobic, senyawanya akan merusak strukteus sel dengan cara masuk kedalam lipopolisakarida yang ada dalam membran sel (Utami, dkk. 2019). Alpha-Humulene Merupakan ligan terbaik yang didapat dari protein target 1WS1 dengan tanaman adas bintang, dengan nilai binding affinity $-6,4$ $\mathrm{kkal} / \mathrm{mol}$ dan nilai RMSD 0. RMSD bernilai 0 menunjukkan bahwa konformasi ligan native hasil docking mendekati konfirmasi sesungguhnya (Prabowo, 2018). Seskuiterpen bisiklik alami, $\beta$-caryophyllene $\quad$ ( $\mathrm{BCP}$ ) dan $\beta$-caryophyllene oxide ( $\mathrm{BCPO}$ ), terdapat di sejumlah besar tumbuhan di seluruh dunia.

Baik BCP dan BCPO ( BCP (O)) memiliki aktivitas antikanker yang signifikan, yang memengaruhi pertumbuhan dan proliferasi berbagai sel kanker. BCP merupakan salah satu komponen aktif utama minyak atsiri yang berasal dari tumbuhan rempah dan pangan dalam jumlah besar (Fidyt,K., dkk, 2016). Minyak esensial dan anethole, diuji pada aorta tikus dengan atau tanpa endotelium, menunjukkan aktivitas vasorelaksan NO-independent yang sebanding pada konsentrasi antiplatelet yang telah terbukti bebas dari efek sitotoksik in vitro (Tognolini, dkk, 20007). Anethole bersifat bakterisidal dan memberikan aksi pembunuhan cepat pada sel $V$. cholerae dan bisa menjadi kandidat obat antimikroba yang potensial, terutama terhadap infeksi yang dimediasi oleh MDR $V$. cholerae (Zahid, dkk, 2015). Minyak terpentine dari Jawa Timur menurut penelitian mengandung $82,9 \% \alpha$-pinene. Terpineol sebagai hasil sintesis dari $\alpha$-pinene merupakan bahan kimia yang digunakan sebagai campuran pada industri kosmetik sebagai parfum, dalam industri farmasi sebagai anti jamur dan anti serangga, desinkfektan dan lain-lain (Daryono, 2015).

\section{KESIMPULAN}

Cengkeh memiliki potensi antimikroba yang menjanjikan. Efektivitas cengkeh dalam menghabat mikroorganisme memiliki spektrum yang luas mencakup bakteri, jamur, protozoa, dan virus. Aktivitas antimikroba ekstrak etanol, metanol, aseton, minyak atsiri cengkeh memberikan aktivitas antimikroba pada bakteri Gram positif dan Gram negatif. Cengkeh menunjukkan aktivitas bakteriostatik dan bakteriosidik. 
DAFTAR PUSTAKA

Alisa., Dkk. 2015. Sintesis Eugenol Menjadi 2-Metoksi-4-(1-Propenil) Fenol Melalui Reaksi Isomerisasi Dan Aplikasinya Sebagai Bahan Suplemen Pada Mouthwash. Jurnal. Vol.3 No.2.

Anacarso, I., Sabia, C., Niederhäusern, S. De, Condò, C., Bondi, M., Messi, P., Anacarso, I., Sabia, C., \& Niederhäusern, S. De. (2017). In Vitro Evaluation of The Amoebicidal Activity Of Rosemary ( Rosmarinus Officinalis L .) And Cloves ( Syzygium Aromaticum L . Merr . \& Perry ) Essential Oils Against Acanthamoeba Polyphaga Trophozoites. Natural Product Research, 6419(November), 1-6. Https://Doi.Org/10.1080/14786419 .2017 .1399390

Batool, F., \& Shahzad-Ul-Hussan, S. (2019). Inhibition Of Dengue Virus Protease By Eugeniin, Isobi $\mathrm{Fl}$ Orin, And Bi Fl Orin Isolated From The Flower Buds Of Syzygium Aromaticum (Cloves). 210.

Https://Doi.Org/10.1021/Acsomeg a. $8 \mathrm{~b} 02861$

Daryono, Elvianto Dwe. 2015. Sintesis A-Pinene Menjadi A-Terpineol Menggunakan Katalis H2SO4 Dengan Varisi Suhu Reaksi Dan Volume Etano. Jurnal Teknik Kimia USU, Vol.4. No.2.

Eldin, H. M. E. (2019). Potent Lethal Effect Of Syzygium Aromaticum Essential Oil On Blastocystis Spp $\therefore$ An In Vitro Study. Https://Doi.Org/10.21608/Puj.2019 .10650 .1035

Fagere, Z. O., \& Magboul, A. Z. Al. (2016). Antibacterial Activity Of Clove Oil Against Microorganisms At Khartoum State, Sudan. Net Journals, 4(December), 122-128.
Fidyt, Klaudyna. Et Al. 2016. $B$-Caryophyllene

And B-Caryophyllene OxideNatural Compounds Of Anticancer And Analgesic Properties. Cancer Medicine. Vol.5(10).

Hoque, M. M., Bari, M. L., Juneja, V. K., \& Kawamoto, S. (2008). Ethanol, Aqueous Extracts, And Essential Oils Of Cloves (. Food Bourn Pathogens And Disease, 72, 9-21.

Huda, M., Rodiansyah, \& Ningsih, D. S. (2018). 1. Efektivitas Ekstrak Bunga Cengkeh ( Eugenia Aromatica ) Terhadap Pertumbuhan Bakteri Staphylococcus Aureus Extract Effectiveness Of Cengkeh Flower ( Eugenia Aromatica ) On Growth Of Bacteria Staphylococcus Aureus. Jurnal Analis Kesehatan, 7(1), 710-716.

Islamuddin, M., Sahal, D., \& Afrin, F. (2014). Apoptosis-Like Death In Leishmania Donovani Promastigotes Induced By Eugenol-Rich Oil Of Syzygium Aromaticum. 74-85. Https://Doi.Org/10.1099/Jmm.0.06 4709-0

Journal, B. (2011). Evaluation Of Antifungal Activity In Essential Oil Of The Syzygium Aromaticum (L.) By Extraction, Purification And Analysis Of Its Main Component Eugenol Inder Singh Rana*, Aarti Singh Rana, Ram Charan Rajak Research \& Development Center, Kilpest India Ltd., Govindpura, Bhopal-462023, India. 1269-1277.

Journal, I., Ijbb, B., Rahman, M. M., Rahman, M. A., Islam, M. S., \& Alam, M. F. (2011). In Vitro Controlling Of Selected Human Diarrhea Causing Bacteria By Clove Extracts ( Syzygium Aromaticum L .). 1(2), 17-26. 
Kumar, Y., Agarwal, S., Srivastava, A., Kumar, S., \& Agarwal, G. (2014). Antibacterial Activity Of Clove ( Syzygium Aromaticum ) And Garlic ( Allium Sativum ) On Different Pathogenic Bacteria. International Journal of Pure \& Applied Bioscience, 2(3), 305-311.

Lova, I. P. S. T., Wijaya, W. A., Paramita, N. L. P. V., \& Putra, A. A. R. Y. (2018). Perbandingan Uji Aktivitas Antibakteri Minyak Atsiri Daun, Tangkai Bunga Dan Bunga Cengkeh Bali (Syzygium Aromaticum L.) Terhadap Bakteri Propionibacterium Acne Dengan Metode Difusi Disk. Jurnal Kimia, 30.Https://Doi.Org/10.24843/Jche m.2018.V12.I01.P06

Machado, M., Dinis, A. M., Salgueiro, L., Custódio, J. B. A., Cavaleiro, C., \& Sousa, M. C. (2011). Experimental Parasitology AntiGiardia Activity Of Syzygium Aromaticum Essential Oil And Eugenol: Effects On Growth, Viability , Adherence And Ultrastructure. Experimental Parasitology, 127(4), 732-739. Https://Doi.Org/10.1016/J.Exppara .2011 .01 .011

Marcía Fuentes, J. A., Fernandez, I. M., Aleman, R. S., Maldonado, S. A. S., Roger, L. F., Herrera Funez, N., Chavarría, L. A., \& Kayanush, A. (2020). Chemical Characterization Of The Essential Oil Of Syzygium Aromaticum And Its Antimicrobial Activity Against A Probiotic Lactobacillus Acidophilus. European Scientific Journal ESJ, 16(15), 33-42. Https://Doi.Org/10.19044/Esj.2020 .V16n15p33

Mehmood, Y., Farooq, U., Yousaf, H., Riaz, H., Mahmood, R. K., Nawaz, A., Abid, Z., Gondal, M., Malik, N. S., Barkat, K., \& Khalid, I. (2020). Antiviral Activity Of Green
Silver Nanoparticles Produced Using Aqueous Buds Extract Of Syzygium Aromaticum. 839-845.

Mohamed, S. G., \& Badri, A. M. (2017). Antimicrobial Activity Of Syzygium Aromaticum And Citrus Aurantifolia Essential Oils Against Some Microbes In Khartoum, Sudan. EC Microbiology, 6, 253259.

Moon, S., Kim, H., \& Cha, J. (2011). Synergistic Effect Between Clove Oil And Its Major Compounds And Antibiotics Against Oral Bacteria. Archives of Oral Biology, 56(9), 907-916. Https://Doi.Org/10.1016/J.Archora lbio.2011.02.005

Nuñez, L., \& D'Aquino, M. (2012). Microbicide Activity Of Clove Essential Oil (Eugenia Caryophyllata). Brazilian Journal Of Microbiology, 43(4), 12551260.Https://Doi.Org/10.1590/S15 17-83822012000400003

Nzeako, B. C., Al-Kharousi, Z. S. N., \& Al-Mahrooqui, Z. (2006). Antimicrobial Activities Of Clove And Thyme Extracts. Sultan Qaboos University Medical Journal, 6(1), 33-39.

Packyanathan, J. S., \& Prakasam, G. (2017). Antibacterial Effect Of Clove Oil Against Clinical Strains Of Escherichia Coli. Journal of Pharmaceutical Sciences And Research, 9(7), 1203-1204.

Paliling, A., Posangi, J., \& Anindita, P. S. (2016). Uji Daya Hambat Ekstrak Bunga Cengkeh (Syzygium Aromaticum) Terhadap Bakteri Porphyromonas Gingivalis. E-GIGI, 4(2). Https://Doi.Org/10.35790/Eg.4.2.2 016.14159

Pandey, A., \& Singh, P. (2011). Antibacterial Activity of Syzygium Aromaticum (Clove) With Metal 
Ion Effect Against Food Borne Pathogens. 1(2), 69-80.

Parthasarathy, H., \& Thombare, S. (2013). Evaluation of Antimicrobial Activity of Azadirachta Indica , Syzygium Aromaticum And Cinnamomum Zeyalnicum Against Oral Microflora . 2, 27-29.

Pathirana, H. N. K. S., Wimalasena, S. H. M. P., Desilva, B. C. J., Hossain, S., \& Gang-Joon, H. (2019). Antibacterial Activity Of Clove Essential Oil And Eugenol Against Fish Pathogenic Bacteria Isolated From Cultured Olive Flounder (Paralichthys Olivaceus). Slovenian Veterinary Research, 56(1), 31-38. Https://Doi.Org/10.26873/SVR590-2018

Pavesi, C., Banks, L. A., \& Hudaib, T. (2018). Antifungal And Antibacterial Activities Of Eugenol And Non-Polar Extract Of Syzygium Aromaticum L. Journal Of Pharmaceutical Sciences And Research, 10(2), 337-339.

Prabowo, Sri., Santoso, Broto. 2018. Profil In Silico Interaksi Senyawa Alam Ketummbar Dan Adas Bintang Sebagai Inhibitor Peptida Deformilaasw Mycobacterium Tuberculosis (3SVJ Dan 1WS1) Menggunakan Bantuan Pyrx-Vina. STIKES PKU Muhammadiyah, Surakarta.

Saad, A., \& Karkosh, A. (2012). Study Of In Vitro Antibacterial Activity Of The Essential Oils Of Cloves ( Syzygium Aromaticum ) And The Effect Of Temperature On Antibacterial Activity. Euphrates Journal Of Agriculture Science, 4(1), 15-19.

Saikumari, D., Rani, S. K. S., \& Saxena, N. (2016). Antibacterial Activity Of Syzigium Aromaticum L. (Clove). International Journal
Of Current Microbiology And Applied Sciences, 5(11), 484-489. Https://Doi.Org/10.20546/Ijcmas.2 016.511 .056

Sciences, A. (2014). Journal of Experimental Biology And Agricultural Sciences Antifungal Activity Of Clove ( Syzygium Aromaticum L .) Essential Oil Against Phytopathogenic Fungi Of Tomato ( Solanum Lycopersicum L ) In Algeria. 2(2320).

Shoaib, A., Saeed, G., \& Ahmad, S. (2014). Antimicrobial Activity And Chemical Analysis Of Some Edible Oils ( Clove , Kalonji And Taramira ). 13(46), 4347-4354. Https://Doi.Org/10.5897/AJB2014. 13683

Suhendar, U., \& Fathurrahman, M. (2019). Aktivitas Antibakteri Ekstrak Metanol Bunga Cengkeh (Syzygium Aromaticum) Terhadap Bakteri Streptococcus Mutans. Fitofarmaka: Jurnal Ilmiah Farmasi, 9(1), 26-34. Https://Doi.Org/10.33751/Jf.V9i1. 1257

Tognolini, M., Ballabeni, V., Bertoni, S., Bruni, R., Impicciatore, M. Dan Barocelli, E. (2007). Protective Effect Of Foeniculum Vulgare Essential Oil And Anethole In An Experimental Model Of Thrombosis. Pharmacologycal Research 56: 254-260.

Utami, Retno., Dkk. 2019. Aktivitas Ekstrak Batang Cengkeh (Syzigium Aromaticum) Terhadap Pertumbuhan Bakteri MethicillinResisten Staphylococcus Aureus (MRSA). Jurnal. UNIMUS. Vol.2

Xu, J. G., Liu, T., Hu, Q. P., \& Cao, X. M. (2016). Chemical Composition, Antibacterial Properties And Mechanism Of Action Of Essential Oil From Clove Buds Against Staphylococcus Aureus. Molecules, 21(9), 1-13. 
Https://Doi.Org/10.3390/Molecule s21091194

Yazdanpanah, L., \& Mohamadi, N. (2014). Antifungal Activity Of The Clove Essential Oil From Syzygium Aromaticum On Paecilomyces Variotii Agent Of Pistachio Dieback. 4(6), 42-45.

Zahid,M. Et Al. 2015. Anethole Inhibits Growth Of Recently Emergrd Multidrug Resistant Toxigenic Vibrio Cholerae O1 El Tor Variant Strains In Vitro. J.Vet.Med.Sci. 2015. Vol.77(5): 535-540
Zahro, L., R. Agustini. 2013. Uji Efektivitas Antibakteri Ekstrak Kasar Saponin Jamur Tiram Putih (Pleurotus Ostreatus) Terhadap S. Aureus Dan E. Coli. Journal Of Chemistry. 2(2): 120-129.

Zainol, S. N., Mohd Said, S., Abidin, Z. Z., Azizan, N., Majid, F. A. A., \& Jantan, I. (2017). Synergistic Benefit Of Eugenia Caryophyllata L. And Cinnamomum Zeylanicum Blume Essential Oils Against Oral Pathogenic Bacteria. Chemical Engineering Transactions, 56(July 2018),

1429-1434.

Https://Doi.Org/10.3303/CET1756

239 


\section{LAMPIRAN.}

Lampiran 1. Mikroorganisme yang dihambat/dibunuh oleh cengkeh Mikroorganisme Bakteri Gram positif Spesies Mikroorganisme Referensi

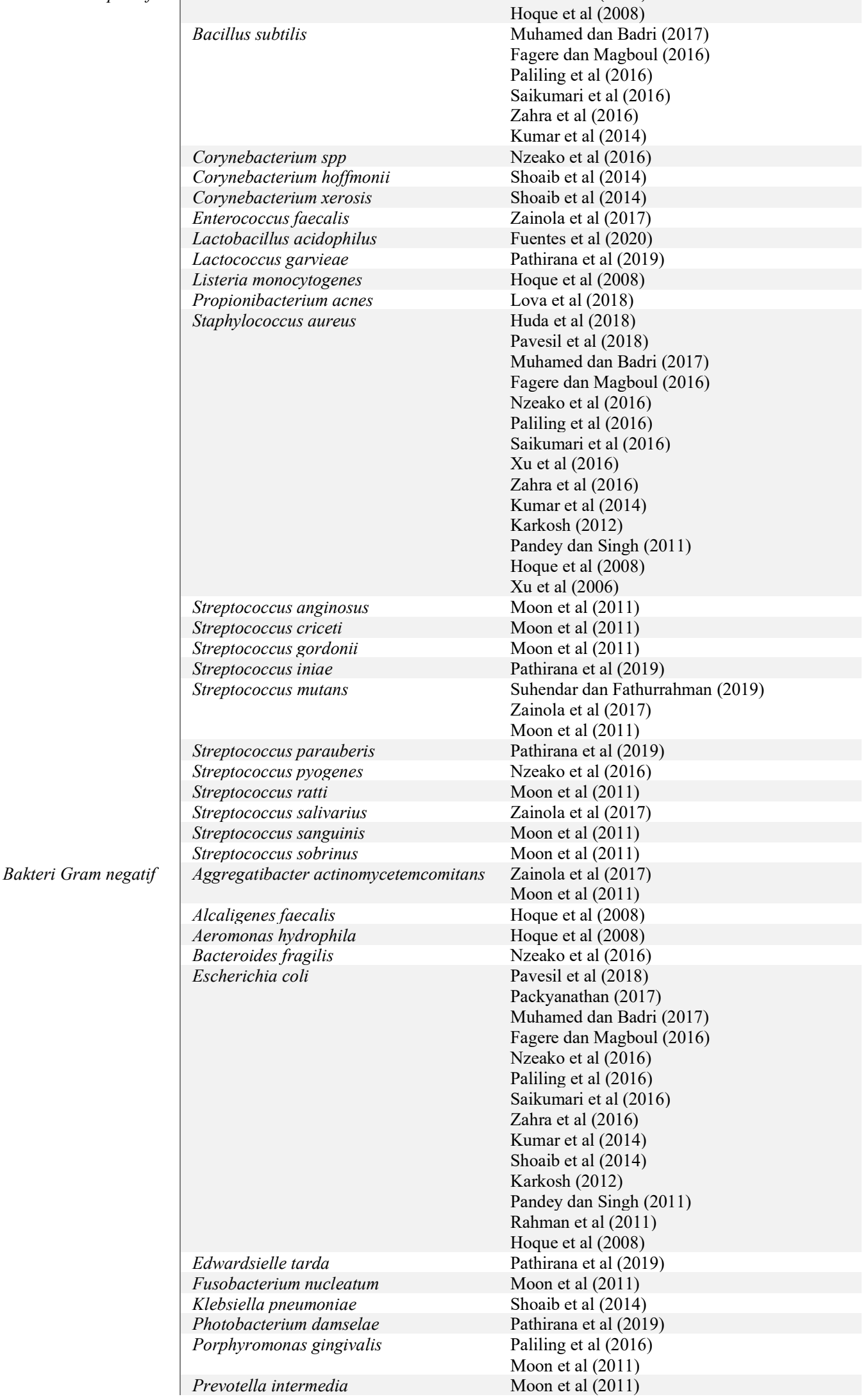




\begin{tabular}{|c|c|c|}
\hline & Proteus mirabilis & Rahman et al (2011) \\
\hline & Pseudomonas aeruginosa & Muhamed dan Badri (2017) \\
\hline & & Fagere dan Magboul (2016) \\
\hline & & Nzeako et al (2016) \\
\hline & & Paliling et al (2016) \\
\hline & & Saikumari et al (2016) \\
\hline & & Zahra et al (2016) \\
\hline & & Shoaib et al (2014) \\
\hline & & Pandey dan Singh (2011) \\
\hline & & Hoque et al (2008) \\
\hline & Pseudomonas putida & Hoque et al (2008) \\
\hline & Salmonella Enteritidis & Hoque et al (2008) \\
\hline & Salmonella spp & Nzeako et al (2016) \\
\hline & Salmonella typhi & Muhamed dan Badri (2017) \\
\hline & & Kumar et al (2014) \\
\hline & & Shoaib et al (2014) \\
\hline & Salmonella Typhimurium & Rahman et al (2011) \\
\hline & Shigella dysenteriae & Rahman et al (2011) \\
\hline & Vibrio harveyi & Pathirana et al (2019) \\
\hline & Vibrio ichthyoenteri & Pathirana et al (2019) \\
\hline & Vibrio parahaemolyticus & Hoque et al (2008) \\
\hline & Yersinia enterocolitica & Rahman et al (2011) \\
\hline Jamur & Aspergillus sp. & Rana et al (2011) \\
\hline & Candida albicans & Nzeako et al (2016) \\
\hline & & Muhamed dan Badri (2017) \\
\hline & & Pavesil et al (2018) \\
\hline & Fusarium commune & Kadar et al (2014) \\
\hline & Fusarium moniliforme & Rana et al (2011) \\
\hline & Fusarium oxysporum & Rana et al (2011) \\
\hline & $\begin{array}{l}\text { Fusarium oxysporum f.sp radicis } \\
\text { lycopersici }\end{array}$ & Kadar et al (2014) \\
\hline & Fusarium redolens & Kadar et al (2014) \\
\hline & Mucor sp. & Rana et al (2011) \\
\hline & Microsporum gypseum & Rana et al (2011) \\
\hline & Paecilomyces variotii & Yazdanpanah dan Mohamadi (2014) \\
\hline & Trichophyton mentagrophytes & Shoaib et al (2014) \\
\hline & Trichophyton rubrum & Rana et al (2011) \\
\hline Protozoa & Acanthamoeba polyphaga & Anacarso et al (2017) \\
\hline & Blastocystis spp. & Eldin (2019) \\
\hline & Giardia lamblia & Machado et al (2011) \\
\hline & Leishmania donovani & Islamuddin et al (2014) \\
\hline & Plasmodium berghei & Taher et al (2018) \\
\hline & Plasmodium falciparum & Hermanto et al (2013) \\
\hline Virus & Dengue virus (DENV) & Saleem et al (2019) \\
\hline & Newcastle disease virus (NDV) & Mehmood et al (2020) \\
\hline
\end{tabular}

\section{Lampiran 2. Senyawa yang terkandung dalam cengkeh}

\begin{tabular}{|c|c|}
\hline Senyawa & Referensi \\
\hline 4-Allylanisole & Xu et al (2016) \\
\hline Anethol & Xu et al (2016) \\
\hline (E) - $\gamma$ bisbolene & Zainola et al (2017) \\
\hline Cadalene & Pathirana et al (2019) \\
\hline Cadinene & $\begin{array}{l}\text { Pathirana et al (2019) } \\
\text { Xu et al (2016) }\end{array}$ \\
\hline$\gamma$-Cadinene & Machado et al (2011) \\
\hline$\Delta$-Cadinene & Machado et al (2011) \\
\hline Cadina-1(10),4-diene & Islamuddin et al (2014) \\
\hline Calacorene & Fuentes et al (2020) \\
\hline Calamene & Fuentes et al (2020) \\
\hline Z-Calamenene & Machado et al (2011) \\
\hline L-Calamenene & Islamuddin et al (2014) \\
\hline Camphene & Machado et al (2011) \\
\hline L-Camphor & Islamuddin et al (2014) \\
\hline Caryophyllene oxide & Fuentes et al (2020) \\
\hline & Pathirana et al (2019) \\
\hline & $\mathrm{Xu}$ et al (2016) \\
\hline & Islamuddin et al (2014) \\
\hline & Machado et al (2011) \\
\hline$\alpha$-Caryophyllene & Xu et al (2016) \\
\hline$\beta$-Caryophyllene & Fuentes et al (2020) \\
\hline & Pathirana et al (2019) \\
\hline
\end{tabular}




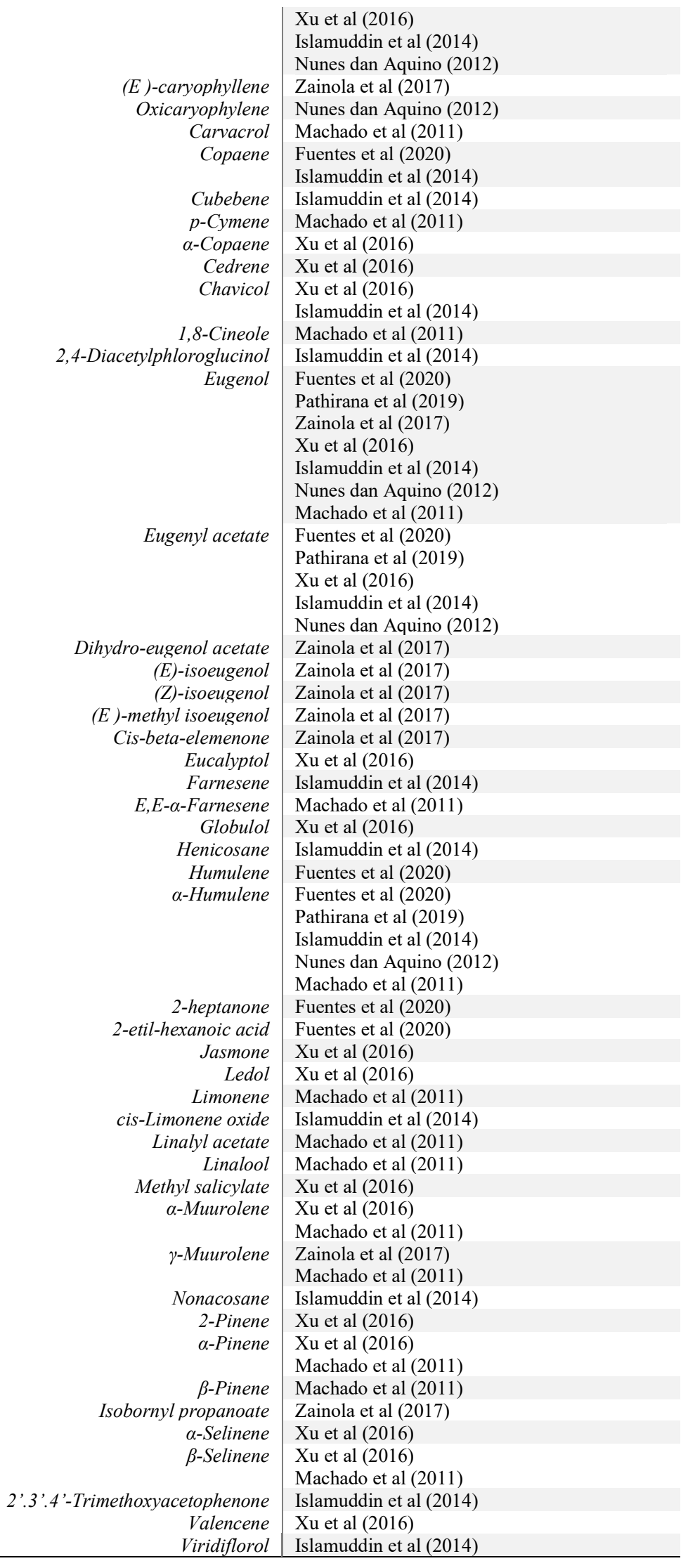

